\title{
Researching the Hazardous Potential of Metallurgical Solid Wastes
}

\author{
Dana - Adriana Iluțiu-Varvara* \\ Technical University of Cluj - Napoca, Faculty of Building Services, \\ 28 Memorandumului, 400114, Cluj - Napoca, Romania
}

Received: 17 August 2015

Accepted: 13 October 2015

\begin{abstract}
The purpose of our paper is to assess the hazardous potential of metallurgical solid wastes stored in a slag dump. We present the experimental procedures for determining chemical composition and for the leaching test of the 10 waste samples taken from the slag dump. According to the data obtained, in the composition of metallurgical solid wastes we identified the following compounds: manganese oxide (MnO), titanium dioxide $\left(\mathrm{TiO}_{2}\right)$, silica $\left(\mathrm{SiO}_{2}\right)$, total iron $\left(\mathrm{Fe}_{\text {total }}\right)$, alumina $\left(\mathrm{Al}_{2} \mathrm{O}_{3}\right)$, lime $(\mathrm{CaO})$, magnesia $(\mathrm{MgO})$, lead oxide $(\mathrm{PbO})$, zinc oxide $(\mathrm{ZnO})$, chromium trioxide $\left(\mathrm{Cr}_{2} \mathrm{O}_{3}\right)$, vanadium pentoxide $\left(\mathrm{V}_{2} \mathrm{O}_{5}\right)$, and phosphorus pentoxide $\left(\mathrm{P}_{2} \mathrm{O}_{5}\right)$. According to the leaching test, metallurgical solid wastes contain several heavy metals that can potentially be hazardous for all environmental factors (soil, water, and air). The content of hazardous heavy metals in the metallurgical wastes varies within the following limits: As (0.311-0.614 mg/L), Cr (0.192-2.514 mg/L), Mo (0.113-0.624 mg/L), Cd (0.104-0.479 mg/L), Pb (0.112-0.869 mg/L), Ni $(0.112-3.212 \mathrm{mg} / \mathrm{L}), \mathrm{Zn}(0.173-3.313 \mathrm{mg} / \mathrm{L})$, and $\mathrm{Hg}(0.037-0.079 \mathrm{mg} / \mathrm{L})$. From the point of view of the arsenic and mercury concentrations, the 10 samples of solid metallurgical wastes exceed the limit values for hazardous wastes.
\end{abstract}

Keywords: metallurgical wastes, waste characterization, pollution, slag dump, heavy metals

\section{Introduction}

Waste means any substance or object that the holder disposes of or is required to dispose of according to European law [1]. The disposal of wastes has to be performed without any risk to soil, air, water, plants, and animals, without causing a negative impact on the environment [1,2].

The European Waste Catalogue (EWC) [3] includes all wastes that are meant for disposal or recovery operations. This catalogue includes all metallurgical solid wastes.

*e-mail: dana.varvara@gmail.com
According to the U.S. Environmental Protection Agency [4] and Council Directive 91/689/EEC [5], hazardous waste is a solid waste, or combination of solid wastes, which due to its quantity, concentration, or physical, chemical, or infectious characteristics may either cause or significantly contribute to an increase in mortality or an increase in serious irreversible or incapacitating reversible illness; or pose a substantial actual or potential hazard to human health or the environment when improperly treated, stored, transported, or disposed of, or otherwise managed.

The metallurgical industry produces significant amounts of waste, and this entails a constant risk for the environment and people. The types of metallurgical solid waste are: metallurgical slag and dust, sludge from the wet 
dedusting of burned gases, and melting loss. Metallurgical wastes contain various hazardous compounds that can be harmful to people and their environment [6-10].

The total quantity of metallurgical solid wastes continues to grow. The storage of these wastes involves occupying large areas of land, the contamination potential of all environmental factors (air, water, and soil), expenses related to land storage, monitoring of all environmental factors near the dump, and adverse effects on human health [11-20].

The environmental hazardous potential of metallurgical wastes is commonly assessed with laboratory leach tests [21] such as the "toxicity characteristic leaching procedure" devised by the U.S. EPA [22]. Chemical measurements are needed to compare the concentrations of hazardous substances present in metallurgical solid wastes with the limit values imposed by the Romanian legislation complying with that in the European Union. In order to be categorized as inert/non-hazardous/hazardous, the metallurgical solid wastes are subject to leaching testing. Romanian legislation establishes criteria and preliminary procedures for waste acceptance in different landfill classes [23].

For the analysis of environmental solid samples, $x$-ray fluorescence (XRF) has the advantage of being a rapid and inexpensive method with a simple sample preparation. Using this technique, the chemical composition of wastes can be determined in a short time. XRF is characterized by good selectivity and low detectability limit of ppm-ppb $[24,25]$.

Atomic absorption spectroscopy (AAS) is ideally suited for the analysis of trace and ultra-trace elements. The technique is characterized by high sensitivity and selectivity, low detectability limit, and high precision $[24,26]$. The cold vapour atomic absorption spectroscopy (CV-AAS) method for determining mercury in environmental samples is characterized by good recovery and reproducibility [24, 27].

The research conducted in this paper is focused on evaluating the hazardous potential of metallurgical solid wastes, stored in the slag dump, through their chemical characterization and determination of the constituents that can be released from these (leaching behavior). The objective of our paper was to add to information regarding the hazardous potential of metallurgical wastes.

\section{Experimental Procedures}

The Păgida metallurgical slag dump is located near Păgida village, which belongs to the town of Aiud in Alba County, Romania. Păgida has an area of 22.45 ha and is located $6 \mathrm{~km}$ from the town of Aiud. Aiud is located in the depression corridor of the Mureş River at the confluence of the Transylvanian Plain to the northeast and of Târnavelor Plateau to the southeast, and the Apuseni Mountains to the west. Aiud is crossed by the meridian $23^{\circ} 10$ west latitude and by the parallel $46^{\circ} 10$ north latitude.

The slag dump has a surface of $26,193 \mathrm{~m}^{2}$ and a storage capacity of $240,000 \mathrm{~m}^{3}$. The types of wastes stored at the slag dump include metallurgical slag from steelmaking in the electric arc furnaces, refractory materials from the electric arc furnaces, acid and basic lining from the electric arc furnaces, foundry waste sands, casting cores, and molds.

The solid wastes landfilled to the dump are generated by the Steel Casting Division of the S.C. Metalurgica Transilvană metallurgical plant in Aiud, Romania. The metallurgical plant has the following divisions: Steel Casting with a total surface of $20,881 \mathrm{~m}^{2}$ distributed in two buildings (one for casting, 14,164 $\mathrm{m}^{2}$, and the other for cleaning, sanding, and storing parts and frames $6,717 \mathrm{~m}^{2}$ ); Heat Treatment at 4,651 $\mathrm{m}^{2}$, with three horizontal furnaces for heat treatments, three vertical furnaces for heat treatments, and a high-frequency annealing machine; and Heavy Forge at 8,453 $\mathrm{m}^{2}$, with five methane gas furnaces, forging presses, and pneumatic hammers.

The Steel Casting Division is used for the technological operations of liquid steelmaking, molding, and casting. It is equipped with three furnaces having capacities of 30 , 10, and 3 tons (for stainless steelmaking). The types of steels made here are non-alloy casting steels, alloy steels, and carbon steels.

The raw materials used in the steelmaking process from which the solid wastes samples originate are old scrap and metallic wastes. The auxiliary materials used in this process are: oxidants (technical gaseous oxygen $\left(\mathrm{O}_{2}\right)$ and iron ore), fondants (lime $(\mathrm{CaO})$ ), fluidizing materials (fluorine $\left(\mathrm{CaF}_{2}\right)$ ), deoxidizer or ferroalloys (FeMn, FeCr, FeNi, FeMo, FeTi, FeV, FeAl, FeSi, SiCa), fuels (petrol coke, electrodes scraps), and alloying elements (Al, Mo, $\mathrm{Cr}, \mathrm{V}, \mathrm{Ti})$.

The casts and ingots are made using pots fitted with argon bubbling devices.

The cleaning division is used for the cleansing and basic heat treatment operations. The debate operation is performed manually. The metal scraps are recovered and reintroduced into the technological process, and the remaining resulting waste (foundry waste sands) is transported and landfilled in a slag dump.

The analyzed waste samples were taken in 2013 from Păgida metallurgical slag dump. Fig. 1 shows the 10 sampling points of the metallurgical solid wastes. The waste samples were collected from 10 points close to the edge of the slag dump because the middle area was not very stable. The sampling points form a close curve around the slag dump. These sampling points were chosen so that the samples should be as representative as possible; they cover all types of wastes stored in this slag dump; they are approximately equally distributed around the slag dump and have samples from all the areas of the slag dump. The sampling points were recorded using GPS.

For a better representation, the samples consist of a mixture of solid wastes taken from a circle with a radius of $10 \mathrm{~m}$ around each of the 10 sampling points. Each sample consists of eight subsamples of solid wastes. Eight sub sampling points represent the north, northeast, east, southeast, south, southwest, west, and northwest directions. 


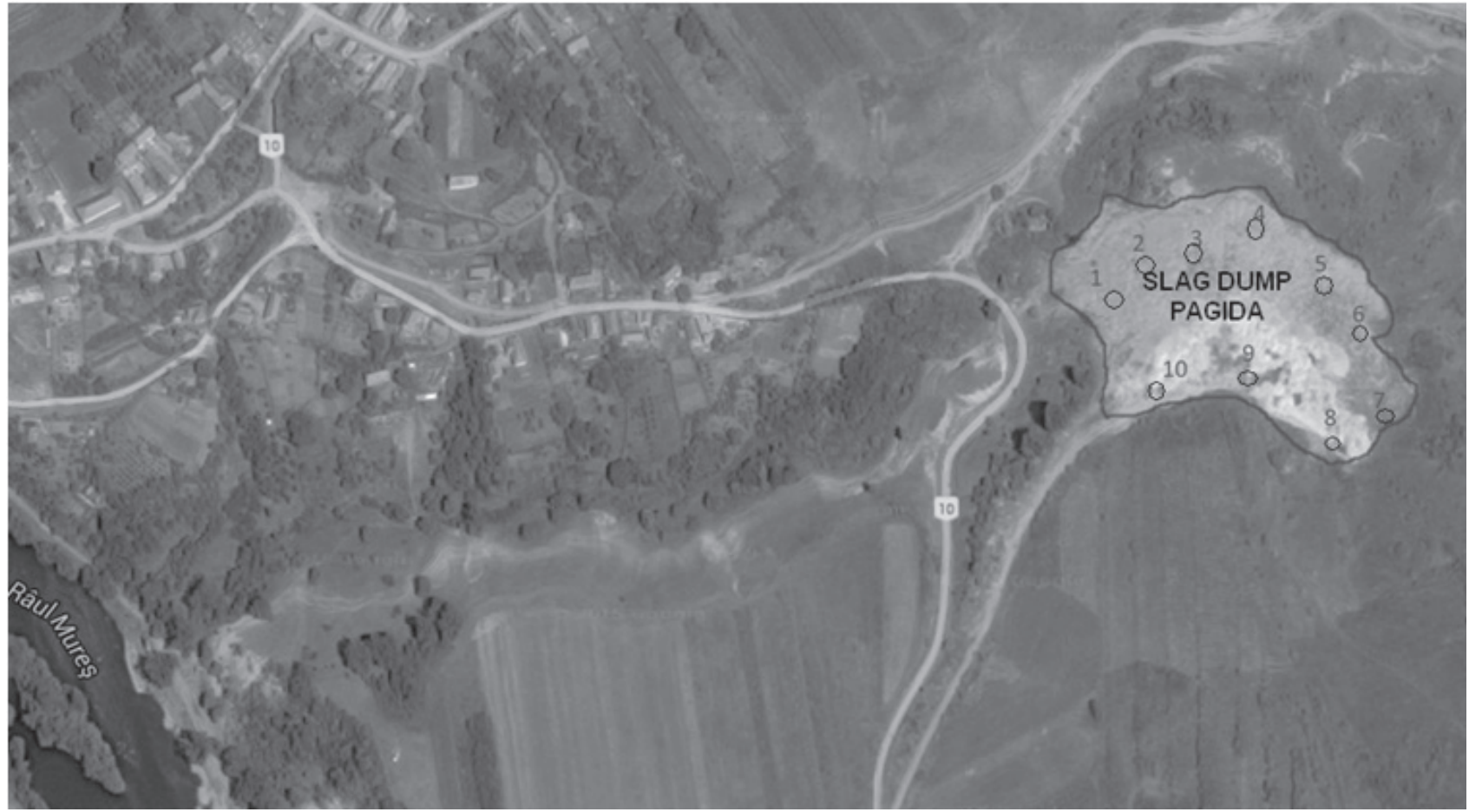

Fig. 1. Distribution of sampling points from the Păgida metallurgical slag dump in Alba County, Romania.

The selection of the research methods is based on the following considerations:

- XRF provides a rapid and non-destructive method for analyzing trace and major elements in environmental solid samples. The method is characterized by good selectivity and a low detectability limit of ppm-ppb [24, 25].

- Using AAS more than 50 metals and metalloids can be analyzed down to the trace and ultra-trace ranges. The significant advantages of AAS are its high selectivity and detection sensitivity, low detectability limit, and accurate and rapid determinations. AAS methods are suitable for monitoring the levels of heavy metals in environmental samples [24, 26].

- Cold vapour atomic absorption spectroscopy is extremely sensitive for mercury determination. CVAAS is used for mercury trace analysis because of its excellent detection limits and relative lack of interference [24, 27].

The instrumentation used for sample preparation included Kern Balances (Kern \& Sohns, Germany), Retsch sieving shaker AS200 (Retsch GmbH, Germany) with mesh size of $4 \mathrm{~mm}$, Sartorius vacuum filtration unit $0.45 \mu \mathrm{m}$ pore size filters (Sartorius Stedim Biotech SA, Germany), and Hettich Universal 320 centrifuge (Hettich, Germany).

The chemical compositions of the 10 waste samples were analyzed by the XRF technique using XRF-Spectro X-LAB 2000 equipment.

The metallurgical solid waste was sieved with a grain size below $4 \mathrm{~mm}$.

The work procedure for the leaching test was made according with the standard SR EN 12457-1/2003 [28]. The leaching test standard refers to a liquid / dry solid ratio of $21 / \mathrm{kg}$ dry solid. Distilled water was used throughout the experiment. For implementing this test we took the following steps: preparation of the solid waste samples for testing; contact between the solid wastes samples and the aqueous solution (the optimum contact time is about 24 hours at $20^{\circ} \mathrm{C}$; the capped bottle was agitated at about 10 rpm for $24 \mathrm{~h}$ at $20^{\circ} \mathrm{C}$ ); the separation of the solid material from aqueous solution (leachate; the decantation time was $15 \mathrm{~min}$ and the mixture was centrifuged and filtered through $0.45 \mu \mathrm{m}$ ); and the chemical characterization of the leachate in order to identify the heavy metals.

The work procedure was made according to SR EN 16192:2012 [29]. The chemical composition of the leachate was established with the help of atomic absorption spectrometry, using an atomic absorption spectrometer SOLLAR S4. The mercury was determined by cold vapor atomic absorption using the EPA method [30]. The concentrations of metals obtained through the leaching test were compared with those mentioned in the reference [23].

\section{Results and Discussion}

Table 1 summarizes the chemical compositions of the 10 samples taken from the waste slag dump and analyzed by XRF. By analyzing the chemical composition of the 10 samples we found in all samples the presence of the following compounds: manganese oxide $(\mathrm{MnO})$, silica dioxide $\left(\mathrm{SiO}_{2}\right)$, total iron $\left(\mathrm{Fe}_{\text {total }}\right)$, alumina $\left(\mathrm{Al}_{2} \mathrm{O}_{3}\right)$, and calcium oxide $(\mathrm{CaO})$; titanium dioxide $\left(\mathrm{TiO}_{2}\right)$ was identified in waste samples $1,7,8$, and 9 , having percentages between 0.1 and $0.41 \%$; magnesia $(\mathrm{MgO})$ 
Table 1. Chemical composition of the wastes samples.

\begin{tabular}{|c|c|c|c|c|c|c|c|c|c|c|c|c|}
\hline \multirow{2}{*}{ No. } & \multicolumn{12}{|c|}{ Chemical composition $[\%]$} \\
\hline & $\mathrm{MnO}$ & $\mathrm{TiO}_{2}$ & $\mathrm{SiO}_{2}$ & $\mathrm{Fe}_{\text {total }}$ & $\mathrm{Al}_{2} \mathrm{O}_{3}$ & $\mathrm{CaO}$ & $\mathrm{MgO}$ & $\mathrm{PbO}$ & $\mathrm{ZnO}$ & $\mathrm{Cr}_{2} \mathrm{O}_{3}$ & $\mathrm{~V}_{2} \mathrm{O}_{5}$ & $\mathrm{P}_{2} \mathrm{O}_{5}$ \\
\hline 1 & 2.9 & 0.1 & 48.1 & 9.9 & 3.1 & 24.8 & 7.1 & 0.6 & 0.6 & - & - & 0.31 \\
\hline 2 & 1.2 & - & 37.3 & 11.1 & 3.2 & 35.4 & - & 1.5 & 6.3 & 1.3 & - & 0.23 \\
\hline 3 & 7.4 & - & 25.4 & 21.2 & 5.9 & 24.5 & 11.9 & - & - & 0.7 & 0.4 & 0.39 \\
\hline 4 & 2.1 & - & 38.1 & 9.6 & 3.7 & 36.9 & 2.6 & 1.9 & - & 3.3 & - & - \\
\hline 5 & 3.1 & - & 40.3 & 10.2 & 4.6 & 27.9 & 9.3 & - & 0.8 & 1.7 & - & - \\
\hline 6 & 3.9 & - & 36.8 & 8.7 & 3.2 & 41.1 & - & 1.6 & 2.4 & - & - & - \\
\hline 7 & 1.7 & 0.2 & 37.1 & 9.1 & 3.3 & 36.1 & 2.5 & 2.1 & 5.2 & 0.6 & - & - \\
\hline 8 & 5.3 & 0.2 & 37.3 & 14.4 & 4.1 & 34.7 & - & - & - & 1.1 & - & - \\
\hline 9 & 4.4 & 0.41 & 21.6 & 18.5 & 4.5 & 23.8 & 15.5 & - & 7.1 & 0.6 & 0.54 & 0.42 \\
\hline 10 & 3.7 & - & 41.2 & 13.6 & 2.9 & 35.1 & - & 0.7 & 0.9 & - & - & - \\
\hline
\end{tabular}

was identified in waste samples $1,3,4,5,7$, and 9, having percentages between 2.5 and $15.5 \%$; lead oxide $(\mathrm{PbO})$ was identified in waste samples $1,2,4,6,7$, and 10 , having percentages between $0.6-2.1 \%$; zinc oxide $(\mathrm{ZnO})$ was identified in waste samples $1,2,5,6,7,9$, and 10 , having percentages between $0.6-7.1 \%$; chromium trioxide $\left(\mathrm{Cr}_{2} \mathrm{O}_{3}\right)$ was identified in waste samples $2,3,4,5,7,8$, and 9 , having percentages between $0.6-3.3 \%$; vanadium pentoxide $\left(\mathrm{V}_{2} \mathrm{O}_{5}\right)$ was identified in waste samples 3 and 9 , having percentages between $0.4-0.54 \%$; phosphorus pentoxide $\left(\mathrm{P}_{2} \mathrm{O}_{5}\right)$ was identified in waste samples $1,2,3$, and 9, having percentages between $0.23-0.42 \%$.

The chemical composition of the wastes varies from sample to sample. The predominant chemical compounds in the composition of the analyzed wastes are: $\mathrm{SiO}_{2}, \mathrm{CaO}$, and $\mathrm{Fe}_{\text {total }}$. In the analyzed solid waste composition there are oxides of heavy metals, which have a negative impact on the environment and human health.

Table 2 presents the concentration of metals obtained through the leaching test and the permissible concentrations according to environmental legislation in force [23]. Analysis of the data presented in Table 2 shows:

Table 2. Leaching results for the 10 metallurgical waste samples.

\begin{tabular}{|c|c|c|c|c|c|c|c|c|}
\hline \multirow{2}{*}{$\begin{array}{l}\text { Sample number } \\
\text { of waste }\end{array}$} & \multicolumn{8}{|c|}{ Concentration of elements $[\mathrm{mg} / \mathrm{L}]$} \\
\hline & As & $\mathrm{Cr}$ & Mo & $\mathrm{Cd}$ & $\mathrm{Pb}$ & $\mathrm{Ni}$ & $\mathrm{Zn}$ & $\mathrm{Hg}$ \\
\hline 1 & $0.314^{x x}$ & $0.218^{x}$ & 0.113 & $0.217^{\mathrm{x}}$ & $0.214^{x}$ & $0.224^{x}$ & 0.365 & $0.041^{x x}$ \\
\hline 2 & $0.367^{x x}$ & $0.926^{x}$ & $0.434^{\mathrm{x}}$ & $0.113^{x}$ & $0.411^{x}$ & 0.119 & $3.279^{x}$ & $0.079^{x x}$ \\
\hline 3 & $0.498^{x x}$ & $0.414^{x}$ & 0.127 & $0.119^{x}$ & 0.112 & 0.115 & 0.227 & $0.044^{x x}$ \\
\hline 4 & $0.359^{x x}$ & $2.514^{x x}$ & 0.129 & $0.117^{x}$ & $0.741^{x}$ & $0.538^{x}$ & 0.173 & $0.051^{x x}$ \\
\hline 5 & $0.614^{x x}$ & $1.432^{\mathrm{x}}$ & 0.151 & $0.125^{x}$ & 0.114 & $3.117^{x x}$ & 0.424 & $0.043^{x x}$ \\
\hline 6 & $0.587^{x x}$ & $0.254^{x}$ & $0.624^{x}$ & $0.479^{\mathrm{xx}}$ & $0.514^{x}$ & 0.118 & $1.284^{\mathrm{x}}$ & $0.056^{x x}$ \\
\hline 7 & $0.489^{x x}$ & $0.313^{x}$ & 0.134 & $0.399^{\mathrm{xx}}$ & $0.869^{x}$ & $3.212^{x x}$ & $2.361^{x}$ & $0.064^{x x}$ \\
\hline 8 & $0.419^{x x}$ & $0.697^{x}$ & 0.125 & $0.353^{\mathrm{xx}}$ & 0.113 & $0.643^{x}$ & 0.184 & $0.037^{x x}$ \\
\hline 9 & $0.327^{x x}$ & $0.324^{x}$ & $0.279^{x}$ & $0.104^{x}$ & 0.119 & 0.112 & $3.313^{x}$ & $0.049^{x x}$ \\
\hline 10 & $0.311^{x x}$ & $0.192^{\mathrm{x}}$ & $0.315^{\mathrm{x}}$ & $0.109^{x}$ & $0.238^{x}$ & $0.347^{x}$ & 0.619 & $0.045^{x x}$ \\
\hline Limit values for inert wastes ${ }^{x}[\mathrm{mg} / \mathrm{L}]$ & 0.06 & 0.1 & 0.2 & 0.02 & 0.15 & 0.12 & 1.2 & 0.002 \\
\hline Limit values for hazardous wastes $^{\mathrm{xx}}[\mathrm{mg} / \mathrm{L}]$ & 0.3 & 2.5 & 3 & 0.3 & 3 & 3 & 15 & 0.03 \\
\hline Limit values for hazardous wastes ${ }^{\mathrm{xxx}}[\mathrm{mg} / \mathrm{L}]$ & 3 & 15 & 10 & 1.7 & 15 & 12 & 60 & 0.3 \\
\hline
\end{tabular}

Legend: $\mathrm{x}$ - concentration of the element that exceeds limit value for inert waste (accepted for inert wastes landfills) $\mathrm{xx}$ - concentration of the element that exceeds limit value for hazardous waste (accepted for non-hazardous waste landfills) $\mathrm{xxx}$ - concentration of the element that exceeds limit value for hazardous waste (accepted for hazardous waste landfills) 
- The concentrations of the elements analyzed do not exceed the limit values for hazardous wastes (accepted for hazardous waste landfills).

- From the point of view of the arsenic and mercury concentrations, the 10 samples of solid metallurgical wastes exceed the limit values for hazardous waste (accepted for non-hazardous waste landfills).

- From the point of view of chromium (sample 4), cadmium (samples 6, 7, and 8) and nickel (samples 5 and 7) concentrations, the metallurgical wastes exceed the limit values for hazardous waste (accepted for nonhazardous waste landfills).

- From the point of view of chromium (except sample 4), molybdenum (samples 2, 6, 9, and 10), cadmium (samples 1-5, 9, and 10), lead (samples 1, 2, 4, 6, 7, and 10), nickel (samples 1, 4, 8, and 10) and zinc (samples 2, 6, 7, and 9) concentrations, the metallurgical solid wastes exceed the limit values for inert waste (accepted for inert waste landfills).

- From the point of view of the molybdenum (samples 1, $3,4,5,7$, and 8), lead (samples 3, 5, 8, and 9), nickel (2, 3, 6, and 9) and zinc (samples 1, 3, 4, 5, 8, and 10) concentrations, the metallurgical solid wastes are in the category of inert wastes.

Metallurgical solid waste contains several heavy metals (As, Cr, Mo, Cd, Pb, Ni, Zn, Hg), which can have a hazardous potential for all environmental factors (soil, air, and water) and human health. Because of the hazardous potential of the heavy metals identified in waste samples, it is necessary to investigate the contamination degree of soil, air, and water environmental factors on the slag dump and on its surrounding area.

\section{Conclusions}

This is the first published study regarding the hazardous potential of metallurgical solid wastes regarding the Păgida metallurgical slag dump in Romania. In the composition of metallurgical solid waste we identified the presence of the following compounds: $\mathrm{MnO}, \mathrm{TiO}_{2}, \mathrm{SiO}_{2}$, total iron $\left(\mathrm{Fe}_{\text {total }}\right), \mathrm{Al}_{2} \mathrm{O}_{3}, \mathrm{CaO}, \mathrm{MgO}, \mathrm{PbO}, \mathrm{ZnO}, \mathrm{Cr}_{2} \mathrm{O}_{3}$, $\mathrm{V}_{2} \mathrm{O}_{5}$, and $\mathrm{P}_{2} \mathrm{O}_{5}$.

According to the leaching test, the concentrations of the elements, identified in the metallurgical solid wastes, varies within the following limits: As (0.311-0.614 $\mathrm{mg} / \mathrm{L}), \mathrm{Cr}(0.192-2.514 \mathrm{mg} / \mathrm{L})$, Mo (0.113-0.624 mg/L), $\mathrm{Cd}$ (0.104-0.479 mg/L), Pb (0.112-0.869 mg/L), Ni (0.112-3.212 mg/L), Zn (0.173-3.313 mg/L), and $\mathrm{Hg}$ $(0.037-0.079 \mathrm{mg} / \mathrm{L})$. The metallurgical solid wastes contains several heavy metals that can be potentially hazardous for all environmental factors (soil, water, and air).

The results can be extrapolated to the other metallurgical slag dumps if the wastes meet the following conditions: they originate from steelmaking in the electric arc furnaces; they come from the casting of steels; and they come from making the following types of steel: nonalloy casting steels, alloy steels, and carbon steels.
The metallurgical solid wastes contain amounts of: chromium, manganese, molybdenum, nickel, and vanadium. The presence of these elements is connected with the metallurgical process and the type of produced steel. These elements are the alloying elements that improve the properties of steel. The solid waste also contains zinc, lead, and arsenic. The presence of these elements is often associated with the composition of charge material, to which old scrap and metallic wastes is added.

\section{Acknowledgements}

This paper was supported by contract No. POSDRU/89/1.5/S/52603, and project 4D-POSTDOC co-funded by the European Social Fund through Sectoral Operational Programme Human Resources Development 2007-13.

\section{References}

1. COUNCIL DIRECTIVE 75/442/EEC of the European Parliament and of the Council of 15 July 1975 concerning "Waste", 1975 (2001/119/EC Commission Decision of 22 January 2001 amending Decision 2000/532/EC replacing Decision $94 / 3 /$ EC establishing a list of wastes pursuant to Article 1(a) of Council Directive 75/442/EEC on waste).

2. COUNCIL DIRECTIVE 91/156/EEC of the European Parliament and of the Council of 18 March 1991 amending Directive 75/442/EEC on Waste. Official Journal L078, 1991.

3. EWC (European Waste Catalogue) established by Commission Decision 2000/532/EC, 2000 amended by Commission Decision 2001/118/EC, 2001.

4. US EPA (United States Environmental Protection Agency), Introduction to hazardous waste identification (40 CFR Parts 261), September, 2005.

5. COUNCIL DIRECTIVE 91/689/EEC of the European Parliament and of the Council of 12 December 1991 on "Hazardous Waste". Official Journal L 377, 31/12/1991, P 00200027, 1991.

6. ILUȚIU-VARVARA D.A. The generation and transfer of pollutant substances in industrial processes. Tehn. Univ. Publishing, Cluj-Napoca, 2007.

7. LEONARD R. P. Hazardous solid wastes from metallurgical industries. Environ Health Perspect. 27, 251, 1978.

8. JEZIERSKI J., JANERKA K. Selected aspects of metallurgical and foundry furnace dust utilization. Pol. J. Environ. Stud. 20 (1), 101, 2011.

9. JAFARI J., KHORASANI N., DANEHKAR A. Ecological risk assessment of lead $(\mathrm{Pb})$ after waste disposal from metallurgical industries. Res. J. Environ. Earth Sci, 2 (4), 139, 2010.

10. WANG L. K., HUNG Y.T., SHAMMAS N. K. Handbook of advanced industrial and hazardous wastes treatment. Taylor \& Francis Group, USA, 2010.

11. ILUȚIU-VARVARA D. A., BRÂNDUŞAN L., PICĂ E.M. Assessment of recycling potential of solid wastes from steelmaking in the electric arc furnaces. Chemical Bulletin of "Politehnica" University of Timişoara, Series of Chemistry and Environmental Engineering. 57 (71), 15, 2012.

12. ACIU C. Use of sawdust in the composition of plaster mortars. ProEnvironment, 7 (17), 30, 2014. 
13. ÇORUH S., ELEVLI S., ERGUN O. N., DEMIR G. Assessment of leaching characteristics of heavy metals from industrial leach waste. Int. J. Miner. Process. 123, 165, 2013.

14. GARCIA-GUINEA J., CORRECHER V., RECIOVAZQUEZ V. L., CRESPO-FEO E., GONZALEZMARTIN R., TORMO L. Influence of accumulation of heaps of steel slag on the environment: determination of heavy metals content in the soils. An. Acad. Bras. Ciênc. 82 (2), 267, 2010

15. ILUTIUU-VARVARA D. A. Researches about the assessment of wastes recycling potential from metallurgical slag dumps. Bulletin UASVM Agriculture. 69 (2), 106, 2012

16. GAVRILESCU E., GAVRILESCU B. F., The atmospheric impact assessment generated by the slag and ash dump in Ceplea Valley. South-west. J. Hortic. Biol. Environ. 1 (1), 77, 2010.

17. LENART A., WOLNY-KOŁADKA K. The effect of heavy metal concentration and soil $\mathrm{pH}$ on the abundance of selected microbial groups within ArcelorMittal Poland Steelworks in Cracow. Bull Environ Contam Toxicol. 90, 85, 2013.

18. WUANA R.A., OKIEIMEN F.E. Heavy metals in contaminated soils: A Review of Sources, Chemistry, Risks and Best Available Strategies for Remediation. International Scholarly Research Network. 1, article ID 402647, 2011.

19. PALDYNA J., KRASNODEBSKA-OSTREGA B., KREGIELEWSKA K., KOWALSKA J., JEDYNAK L., GOLIMOWSKI J., GROBELSKI T., FARBISZEWSKAKICZMA J., FARBISZEWSKA T. The assessment of environmental pollution caused by mining and metallurgy wastes from highly polluted post-industrial regions in Southern Poland. Environ Earth Sci. 68 (2), 439, 2013.

20. SZYNKOWSKA M.I., PAWLACZYK A., LEŚNIEWSKA E., PARYJCZAK T. Toxic metal distribution in rural and urban soil samples affected by industry and traffic. Pol. J. Environ. Stud. 18 (6), 1141, 2009.
21. KIERCZAK J., CHUDY K. Mineralogical, chemical, and leaching characteristics of coal combustion bottom ash from a power plant located in Northern Poland. Pol. J. Environ. Stud. 23 (5), 1627, 2014

22. US Environmental Protection Agency (USEPA), «The Toxicity Characteristics Leaching Procedure». USA Code of Federal Regulations, $40^{\text {th }}$ Edn. Part 261, app. II. Washington, D.C, 1992.

23. Order no. 95/2005 on the establishment of acceptance criteria and preliminary procedures for landfill acceptance of waste and national list of waste accepted in each class. Environment Ministry from Romania, 2005.

24. SZYCZEWSKI P., SIEPAK J., NIEDZIELSKI P., SOBCZYŃSKI T. Research on heavy metals in Poland. Polish J. of Environ. Stud. 18 (5), 755, 2009.

25. TUMUKLU A., YALCIN M. G., SONMEZ M., Detection of heavy metal concentrations in soil caused by Nigde City Garbage Dump, Pol. J. Environ. Stud. 16 (4), 651, 2007.

26. GWOREK B. BIERNACKA E., Influence of technological processes and improper storage of waste on the mercury content and migration in the soil, Pol. J. Environ. Stud. 8 (3), 197, 1999.

27. KOWALSKI A., SIEPAK M., BOSZKE L., Mercury Contamination of Surface and Ground Waters of Poznań, Poland, Pol. J. Environ. Stud. 16 (1), 67, 2007.

28. SR EN 12457-1. Characterization of waste. Leaching test. Compliance test for leaching of granular waste materials and sludges. Part 1: One stage batch test at liquid to solid ratio of $21 / \mathrm{kg}$ for materials with high solid content and with particle size below $4 \mathrm{~mm}$ (without or with size reduction), 2003.

29. SR EN 16192, Characterization of waste. Analysis of eluates. 2012.

30. US EPA (United States Environmental Protection Agency) Method 7471B. Mercury in Solid or Semisolid Waste 2007. 